\title{
Yalova-Gemlik Bölgeleri ve İzmit Yarımadası'nda Yunan Mezalimine Dair İtilaf Devletleri Araştırma Komisyonu Raporları (12-22 Mayıs 1921)
}

\author{
Yrd. Doç. Dr. Mehmet KAYA*
}

$\ddot{O} z e t$

Mondros mütarekesiyle birlikte İtilaf Devletleri Osmanlı Devleti'ni paylaşım planların uygulamaya başladılar. Batı Anadolu'nun Yunanistan'a birakılması bu planların açı bir işaretidir. Yunan ordusunun 1920 Temmuz ayında Yalova ve İzmit çevresini işgal etmesi milli mücadelenin içerisinde önemli bir yer tutmaktadır.

Batı cephesinin kurulmaslyla birlikte Yunan ilerleyişine karşı mücadele ordu aşamasına geçmiştir. 1921 yll Ocak ve Mart aylarındaki İnönü savaşları bu anlamdaki mücadelenin bir ișaretidir. 1920 ortalarindan itibaren Yunan ileri hareketinin genişlemesi, bölgedeki ylkım ve zulümleri de arttırmıştır. Halkın İtilaf Devletleri'ne şikâyetleri 1921 yll Mayıs ayında sonuç vermiş, bir araştırma komisyonu kurulup bölgeye gönderilmistir. Komisyon bölgedeki izlenimlerini rapor haline getirmişstir. Bu rapor ışı̆̆ı̆nda 1921 yll ortalarında Gemlik, Yalova ve İzmit bölgesindeki Yunan ordusu ve çetelerin yağma ve zulümleri Itilaf Devletleri'nce onaylanmış bulunmaktadır.

Anahtar Kelimeler: İzmit livası, Milli Mücadele'de İzmit ve çevresi, İzmit bölgesindeki ylkım ve mezalim

Reports of Inter Allied Commission in the Yalova-Guemlek Regions and Ismid Penisula (12-22 May 1921)

\section{Abstract}

Armistice of Mudros, sharing with the Allied Powers Ottoman Empire began to implement plans. Western Anatolia, Greece, leaving a clear sign that these plans. In

\footnotetext{
Niğde Üniversitesi Fen-Edebiyat Fakültesi Tarih Bölümü Öğretim Üyesi dr.kaya40@hotmail.com
} 
July 1920 the Greek army, Yalova, Izmit, Turkey invaded the environment plays an important role in the national struggle.

With the establishment of the progress of the Greek army to fight against the west wall was the stage. Inönü battles in January and in March 1921 in this sense is a sign of struggle. Expansion of the Greek movement since the mid-1920, destruction and atrocities in the region has increased. Public complaints against Entente troops in May of 1921 proved successful, established a commission of inquiry sent to the region. The Commission has made the region report their impressions. light of this report in mid 1921, the Greek arrmy in Yalova and Izmit and gangs looting and atrocities have been approved by the Allied Powers.

Keywords: Liva of Izmit, Izmit in the National Struggle and the environment, destruction and atrocities in Izmit

\section{Giriş}

Mondros Mütarekesi sonucunda İtilaf Devletleri Anadolu'yu paylaşmaya başladılar. Bir antlaşmanın yapılabilmesi için Osmanlı Devleti'ni 22 Nisan 1920 'da Paris'te yapılacak görüşmelere çağırdılar. Osmanlı Devleti'ni bu görüşmelerde Tevfik Paşa temsil etti. İtilaf Devletleri 11 Mayıs'ta barış şartlarını bildirdiler. ${ }^{1}$ Tevfik Paşa şartların kabul edilemez olduğunu belirtip İstanbul'a geri döndü. ${ }^{2}$

İtilaf Devletleri Osmanlı Devleti'ne sunulan şartları kabul ettirebilmek için baskıya arttırmaya başladılar. Yunan İşgal Kumandanlığı 15 Haziran'dan itibaren faaliyet alanını genişletmeye başladı, Balıkesir işgal edildi. 24 Haziran'da Garp Cephesi Kumandanlığ kuruldu. Kumandanlığa Ali Fuat Paşa'nın atanmasıyla boşalan 20. Kolordu Kumandanlı̆̆ı'na Bekir Sami Bey (Günsav) getirildi. ${ }^{4}$

İtilaf Devletleri komutanları Bursa ve çevresinde yerel yöneticilerden duyulan rahatsızlığı dile getirdiler, şehrin uçaklarla vurulacağı tehdidinde

\footnotetext{
${ }^{1}$ Paris Konferansı'nda Osmanlı Devleti'ne sunulan şartlar hakkında İstanbul'daki İngiliz temsilcisi Amiral Webb'in düşünceleri için. Foreign Office, E 4570/3537/44, Amiral Webb'ten Curzon'a, İstanbul, 11 Mayıs 1920.

${ }^{2}$ BOA, Dâhiliye Nezareti Kalem-i Mahsus Müdüriyeti DH. KMS.57-1/ 50, (1); Saime Yüceer, Bursa'nın İsgali ve Kurtuluş Süreci, Bursa 2001, s.45; Mümtaz Şükrü Eğilmez, Milli Mücadele'de Bursa, İstanbul 1984, s.23; TTK Arşivi, Bekir Sami Bey Dosyası, 7. Defter, 12 Mayis 1920.

${ }^{3}$ Şerafettin Turan, Balıkesir ve Alaşehir Kongreleri ve Hacim Muhittin Çarıklı'nın Kuva-yı Milliye Haturalarl, Ankara 1967, s.35.

4 Bekir Sami Beyin (Günsav)Milli Mücadele'deki faaliyetleri için TTK Arşivi, Bekir Sami Bey Dosyası, 1-VII. Defter; İlhan Selçuk, Yüzbaşı Selahattin'in Romanı, C.II, İstanbul 1987, s.289; Hamdi Gürler, Kurtuluş Savaşı'nda Albay Bekir Sami-Günsav- (Mayıs-Haziran 1919), Genelkurmay Başkanlığı Yayınları, Ankara 1994, s.78.
} 
bulundular. Haziran ayında İngilizlerin İzmit bölgesindeki işgalleri genişleyince liva merkezi Geyve'ye taşındı. Adapazarı, İzmit, Kandıra, Karamürsel kazaları da livaya bağlandı. ${ }^{5}$ Yunan İşgal Kumandanlığının Bursa ve çevresinin Yunan kuvvetlerine bırakılmasına ilişkin teklifini İtilaf Devletleri kabul ettiler. 8 Temmuz sabahı Bursa işgal edildi. ${ }^{6}$ Yunan ordusu ileri hareketine devam ederek kısa bir süre sonra Gemlik ve Yalova'yı işgal etti. İtilaf Devletleri Sevr Antlaşması'nı Osmanlı Devleti'ne 20 A ğustos 1920 'te kabul ettirdiler. ${ }^{8}$ Antlaşmadan güç alan Yunan kuvvetleri Ekim ayından itibaren Karamürsel ve çevresine hâkim oldular.

Bursa ve Gemlik'teki Yunan kuvvetleri 3. Yunan Kolordusuna bağlı olup, kolordu merkezi Bursa idi. Kolorduya bağl1 10. İzmir Tümeninin merkezi Gemlik'te idi. Tümene bağlı 28. Alayın bir taburu Pazarköy'de (Orhangazi), 30. Alayın bir taburu Umurbey'de, üç piyade bölüğünden biri Yalova'da, iki bölük de Gemlik-Pazarköy arasında bulunuyordu. ${ }^{10} 1920$ yılındaki Yunan ordusunun bu dağılımına ilişkiler veriler yanında, 1921 yılı Mart ayı içerisinde de bazı bilgiler mevcuttur. İkinci İnönü Savaşı'nın yaklaştı̆̆ günlerde Bursa ve çevresinde 2. 7. 8. Yunan tümenleri olup, tümenlere bağlı alaylar Pazarköy, Ermeni Sölözü ve Gemlik'te idi. ${ }^{11}$

İzmit bölgesinde Yunan işgaliyle birlikte yağma ve mezalim Rum ve Ermeni çetelerin desteğiyle arttı. Bu mezalim hakkında 6 Ocak 1921'de Gebze Belediye Reisi Sadarete rapor gönderdi. Raporda Yunan askerlerinin beraberlerinde getirdikleri Yeniköylü Rumlarla kasabayı bastıkları, halkın malını gasp edip öldüresiye dövdükleri, zorla selam verdirdikleri gibi çeşitli fiilleri işlediklerinden acilen yardım edilmesini istiyordu. 24 Mart 1921'de Karamürsel Kaymakamı Hüseyin Hilmi Bey Hariciye Nezareti'ne benzer bir rapor gönderdi. Kaymakam raporunda bölgede yapılan mezalime dikkat

\footnotetext{
${ }^{5}$ BCA, Bakanlar Kurulu Ortak Kararları, 30.18.1.1, 1.2.3, 73-3, 07.06.1920.

${ }^{6}$ İşgale kadar Bursa ve çevresinin durumu için bkz BOA, Bab-1 Ali Evrak Odası-Dâhiliye Giden 25 Nisan 1920; BCA, Bakanlar Kurulu Ortak Kararlar1, 030.18.1, 1.4.12, 13.07.1920; Gizli Oturumlarda Atatürk'ün Konuşmaları, (hazırlayan Sadi Borak), İstanbul 1977, s.97; Mustafa Kemal Atatürk, Nutuk, C.I, İstanbul 1984, 383.

${ }^{7}$ Kamil Erdeha, Milli Mücadele Vilayetler ve Valiler, İstanbul 1975, s. 362.

${ }^{8}$ Sevr'in maddeleri için. Foreign Office, E 14076/1/44, Curzon'dan Hardinge'a, Foreign Office, 30 Aralık 1921.

${ }^{9}$ Sabahattin Özel, Kocaeli ve Sakarya Illerinde Milli Mücadele, İstanbul 1987, s.116. İtilaf Devletlerinin Türkiye üzerinde politikaları için New York Times, "Italy Theratens Unity on Turkey", 2 Ağustos 1920.

${ }^{10}$ ATASE Arşivi İSH, Klasör 689, Dosya 129, Fihrist 204.

${ }^{11}$ ATASE Arşivi İSH, Klasör 684, Dosya 129, Fihrist 192.
} 
çekiyor, Rum Patrikhanesi'nin Rum ve Ermeni çeteleri örgütleyerek Şile, Kandıra ve İzmit'e gönderdiğinden acil önlem alınmasını dile getiriyordu. ${ }^{12}$

II. İnönü Savaşı'nda yenilmelerine rağmen Yunan kuvvetleri İzmit bölgesindeki mevkilerini koruyorlard ${ }^{13}$ Mürettep Kolordu Kumandanlığ 1 görevine tayin edilen Albay Kazım Bey 7 Nisan'da Düzce'ye gelerek görevine başladı. ${ }^{14}$ Yunanlıların Bahçecik ve Yeniköy'e taarruzları milli kuvvetler tarafından püskürtüldü. Yunan kuvvetleri 13 Nisan'da İzmit'in kuzey-doğusundaki Çubuklu köyüne çekildiler. Kandıra ve çevresinde Yunanlıların boşalttığ sürdürüyorlard. ${ }^{15}$

İngilizler 9 Nisan'da birlik bulundurdukları İzmit'i 28 Nisan'da boşaltarak Yunanlılara terk ettiler. İzmit'te bulunan 11. Yunan Tümeni İngiliz denetiminden ayrılmış oldu. $\mathrm{Bu}$ düzenleme ile İzmit ve Derince limanları Yunanlılara bırakıldı, Şile ve Gebze İngiliz denetiminde kald ${ }^{16}$ Mayıs ayı milli kuvvetler açısından batı cephesinin düzenlemesi ve keşif hareketleri ile geçti. Yunanlılar da bu ay içerisinde bazı girişimlerde bulundular. Komisyonun geldiği tarihte Bahçecik'te yaşayan Rumlar Yunanlılarca toplanarak İzmit'ten uzaklaştırıldılar. Bölge içerisindeki bazı yolları ulaşımı kolaylaştırmak için düzenlemeye çalıştılar. ${ }^{17}$

\section{1-Araştırma Komisyonu Raporu}

Gemlik, Yalova ve İzmit bölgesinde yapılan mezalimi araștırmak üzere İtilaf Devletleri Nisan ayı ortalarında komisyon oluşturdular. ${ }^{18}$ Komisyonun

\footnotetext{
12 İbrahim Meral, Mütareke'den Cumhuriyet'e (30 Ekim 1918-29 Ekim 1923) Azınlıkların Sosyal, Ekonomik ve Demografik Yapısı ve Dış Ülkelerle Olan ilişkileri, Hacettepe Üniversitesi Atatürk İlkeleri ve İnkılap Tarihi Enstitüsü Yayınlanmamış Doktora Tezi, Ankara 1997, s.150.

${ }^{13}$ Milli Mücadelenin 1921 yılındaki durumu için. New York Times, "Kemalists Report Defeat of Greeks", 26 Mart 1921.

${ }^{14}$ Kazım Özalp, Milli Mücadele, C.I, Ankara 1985, s.177; Ali Fuat Cebesoy, Milli Mücadele Hattralarl, İstanbul 1953, s.488.

15 Şehir ve Kasabaların Harp Bölgeleri Bombardıman, İsgal ve Kurtuluş Tarihleri 19111922, Genelkurmay Harp Dairesi Başkanlığı, Ankara 1977, s.45; T.B.M.M Zabit Ceridesi, Devre 1, C. III, Ankara 1959, s.60.

${ }^{16}$ Zeki Sarıhan, Kurtuluş Savaşı Günlüğ̈̈, C. III, Ankara 1986, s.486.

17 Türk İstiklal Harbi, C.I, Kısım 4, Ankara 1974, s.114, Adnan Sofuoğlu, Milli Mücadele Döneminde Kocaeli, Ankara 2006, s.142.

18 İstanbul'daki İngiliz temsilci H. Rumbold Nisan ayı ortalarında General Harington'a İtilaf Devletleri'nin mezalimi araştırmak için üç ayrı komisyon kurmasını teklif etti. Komisyonlardan birinin Trakya'da, ikincisinin İzmit Yarımadası'nda, üçüncüsünün de Yalova ve Orhangazi'de inceleme yapması öngörülüyordu. Bölgeye gönderilecek komisyonun iki tane olması muhtemelen inceleme heyetinin de ayrı bir komisyon olarak gösterilmesi ile açıklanabilir. Buna bir başka delil de komisyon raporunun İzmit ve Orhangazi’yi de içermesi
} 
görevi bölgedeki mezalimi araştırmak, araştırmaların sonucuna göre rapor hazırlamaktı. Raporda bu araştırmanın ne sebeple yapıldığına dair bir bilgiden söz edilmemektedir. Yerel Türk makamlarının yanı sıra, Rum ve Ermenilerin de bölgede yapılan zulüm ve mezalimi İtilaf Devletleri yetkililerine iletmiş olmaları sonucunda bir komisyon teşkil edilip araştırma yapması kararlaştırılmıştı.

Komisyon üç ayrı devletin temsilcilerinden meydana geliyordu. Kendi bünyesinde bir inceleme heyeti oluşturdu. Komisyon bölgeye dair genel bir rapor hazırladı, ayrıca inceleme heyetinin gözlemlerini içeren günlük de ekte sunuldu. Rapor ve günlükten sonra da genel bir değerlendirme yer alıyordu. ${ }^{19}$

Araştırma komisyonu incelemelerine başlamak üzere 12 Mayıs 1921 sabahı İstanbul'dan hareket etti, akşam Gemlik'e ulaştı. Albay E. Bolletto (İtalya), Yüzbaşı G. Virg komisyonun üyeliklerini, Başkanlığı da Albay Franks (İngiltere) yürütüyordu. Bölgedeki yağma ve katliamları incelemekle görevli heyet daha alt düzeyde idi, heyet başkanı O. R. Van Milllingen idi, Yüzbaşı H. M. Farmar, Yüzbaşı Vitelli, Yüzbaşı Wilkonsy heyetin üyeleriydiler.

Raporun giriş kısmında bölge üzerinde genel bilgilere yer veriliyordu. Gemlik ve Yalova bölgenin en geniş kazaları olup, kırk köyün otuz beşinde Türk nüfusu fazlaydı. Bölge içersinde yer alan Pazarköy ve İznik gölünün batı ve kuzey kısımlarıyla çevrili alanda Ermenilerin yoğun olarak yaşadığ 1 on köyden söz ediliyordu. Rum ve Ermeni köylerinin Türk çeteler (Kemalistler) tarafından yağma edilip yakıldığına dair ifadelere ağırlıktaydı. Kemalistler olarak gösterilen bu kuvvetlerin Kuva-yı İnzibatiye ve Kuva-yı Milliye içerisinde yer alan bazı düzensiz birlikler olduğu bölgedeki mezalimin etkilerinden anlaşılmaktadır.

Gemlik, bölgedeki yağma ve katliamdan kaçan halkın sığınma yeri idi. 10. Yunan Tümeni karargâhı Leonardopulos komutasında Gemlik'te idi. Elmalık, Fulacık, Ortaköy ve İznik’ten 2000 Ermeni, 1500 Türk, 3500 Rum göçmen Gemlik'e geldi. Gemlik’te bu olaylar öncesinde Rumların verdiği abartılı bilgiyle 6000 Rum ve 1000 Türk yaşıyordu. Bursa'nın Ağustos 1920'de Yunan işgaliyle birlikte dokuz aydır bölgede bulunan Yunan

idi. Komisyonların kurulmasına dair Foreign Office, E4286/143/44, Earl Curzon'dan H. Rumbold'a, Foreign Office, 16 Nisan 1921; Foreign Office, E4966/143/44, H.Rumbold'dan Eral Curzon'a, İstanbul, 26 Nisan 1921. İtalya'nın da komisyona temsilci vermek istediğine dair Foreign Office, E 5350/143/44, H. Rumbold'dan Earl Curzon'a, İstanbul, 6 May1s 1921.

${ }^{19}$ House of Common Parliamentary Papers, 1921 [Cmd 1478], Turkey. No.1, (1921), Reports on atrocities in the Districts of Yalova and Guemlek and in the Ismid Penisula, s.2-11. 
müfrezesi sekiz bölükten ibaretti. Pazarköy-Yalova hattında altı bölük olup, biri makineli tüfek bölügü idi. Kaza merkezinde iki bölük, Armutlu'da da yirmi altı kişilik küçük bir müfreze vardı. Bölgede artık Türk yönetiminden söz etmek mümkün değildi. Bunun yanında otoriteyi sağlayacak bir yönetimin henüz oluşmadığı raporda yer alıyordu.

Genel bilgilerden sonra komisyon bölge hakkındaki düşüncesini yansıtmaktadır. $\mathrm{Bu}$ incelemenin 13-20 Mayıs tarihleri arasında devam ettiği anlaşılmaktadır. Komisyon mesaisini ilk iki gününü bölge halkını dinlemeye ayırd1. Bu günlerde (13-14 Mayıs) komisyona Türk, Rum ve Ermenilerden hiç kimse bilgi vermek için gelmedi. Komisyon gözlemlerini maddeler halinde belirtiyordu. Pazarköy kasabası, Çeltikçi, Gedelek (Türk), Çengeller (Ermeni) köyleri yıkılıp yakılmıştı. 15-17 Mayıs günlerinde Mudanya körfezinin kuzey kısımları ile Kumla, Karaca Ali, Narlı, Kapaklı, Fıstıklı köylerinin yandığı komisyonun çalışmalarını yürüttüğü gemiden görülebiliyordu. Rum ve Ermeni çetelerinin Kapakl1, Narlı, Karaca Ali'nin ayın on beşinde yanmaya devam ettiği, Kumla'da ise yirmi sekiz yaşlı erkek ve kadının başlarına vurularak öldürüldüğü, Kapaklı'da bir kişinin yaralı olduğu tespit edilmişti. Yalova bölgesini de ziyaret eden komisyon üyeleri Yalova, Çınarcık, Engürü ve Koca Dere de yaşayan Türk ve Rum sakinlerden yağma ve zulümlerle ilgili bilgi aldılar. Bölgeye yakın olan Akköy ve Samanlı komisyonun çalışma alanına dâhil edilmedi. 300 Türk'ün Akköy ve Samanlı'ya acil yardım yapılmadığından Küçük Kumla'daki mezalimin burada da meydana gelmesinden komisyon endişe duyuyordu. $\mathrm{Bu}$ gözlemler ışığında komisyon üyeleri genel bir metin hazırladılar. ${ }^{20}$

Metinde Ömer Bey, Akköy, Yalova ve Samanlı dışında bütün Türk köylerinin ziyaret edildiği, köylerin iki aydan daha kısa bir süre önce Hıristiyan çeteleri tarafından yağma edilip yakıldığı, bazı sakinlerin tahribat öncesinde köylerini terk ettikleri, diğerlerinin de saldırılar başladığında dağlara kaçtıkları, bir kısmının da katliama maruz kaldığ 1 belirtiliyordu. Komisyon bu katliamların planlı bir şekilde yapıldığı kanaatine varmıştı. Yakılmış adam ve çocuklar, tecavüze uğratıp öldürülmüş kadınlara dair Türkler geniş bilgiler sundular Dağlara kaçan insanların sayısı hakkında bir bilgiye ulaşmak mümkün değildi. Yunan ordusunun işgal ettiği yerlerde Türkler büyük bir şiddete ve zulme maruz kalmışlardı. Komisyon bu faaliyetlerin işgal ordusuyla bağlantılı olduğu kanaatini edinmişti. Ermeni ve Rum göçmenlere yardım eden Yunan ordusunun Pazarköy'ün işgalinden sonra bile 1500 civarında Türk'e hiçbir şekilde yiyecek ve tıbbi yardım yapmadıkları da komisyonun hazırladığı metinde yer alıyordu.

\footnotetext{
${ }^{20}$ House of Common Parliamentary Papers, s.2-3.
} 
Raporda Kuva-yı Milliyenin faaliyetlerinden de söz ediliyordu. Bu kuvvetlerin Yunan ordusu tarafindan henüz işgal edilmeyen İznik gölünün kuzeyinde bulunduğu, Yalova kıyılarında yaşayan Hıristiyan halka karş1 yağma ve yıkım hareketlerinin yürütüldüğü belirtiliyordu. Kuva-yı Milliye ve diğer Türk ve Rum çeteler arasında halka karşı yıkım ve zulümlerin olduğu, ama bunların doğrulatılamadığı ifade ediliyordu.

Ermeni köyü Çengellerin Nisan ayı içerisinde Türk çeteler tarafından yakıldığı dile getiriliyordu. Köy halkı önce Pazarköy'e, daha sonra da Gemlik'e göç etmişlerdi. Yunan ordusu tarafından da Pazarköy işgal edilip yıkılmıştı. Yunan askerleri ve Hıristiyan sakinler de bölgenin Türk çetelerce yağmalanıp, gayrimüslim nüfusun bölgeden göç etmeye zorlandığını dile getirdiler. Yunan askeri müfrezesi Narlı'ya girdiğinde Türk çete mensupları ile çatışma çıktı, köy çeteler tarafından yağmalanıp yakıldı, bir asker de bu saldırıda öldü. Bir başka anlatımda da yedi Rum'un Armutluda öldürüldüğü söylenmişti. Mayıs'ın on ikinci günü iki Rum gencinin Gemlik'ten Kumla'ya giderken sahilde ölü bulunduğu ifade edildi. Komisyona dolaylı olarak gelen bu bilgi Yunan makamlarınca doğrulanmadı. Türk bölgelerinde yağma ve yangınlar Rum ve Ermeni çeteler tarafından gerçekleştiriliyordu. Yunan ordusunun da bu yıkımın içinde olduğuna dair düşünceler komisyon üyelerinin kanaatini kuvvetlendiriyordu. ${ }^{21}$

Yunan Kumandanlığının bölgede yaşanan olaylar hakkında bilgi vermediği, komisyon üyelerinin dikkatinden kaçmamıştı. Yıkım daha çok Türk köylerinde gerçekleştiğinden bu konuda Yunan ordusunun gerekli tedbirleri almadığı görülüyordu. Komisyonun bu yazısı doğrultusunda Küçük Kumla'da Türklerin korunması için 15 Mayıs akşamı gerekli önlemler alındı. Bir Yunan müfrezesi 12-15 Mayıs tarihleri arasında GemlikArmutlu arasına gönderildi. Ancak görevi bölgeyi silahsızlandırmak ve temizlemekti, halkı yangın ve yağmadan korumakla sorumlu değildi. Komisyonun olayların üzerine gidip aydınlığa kavuşturmaya çalıştı̆̆ vurgulanıyordu. Olayların Mart ayı sonunda meydana geldiği, bunun Yunan ileri harekâtı sırasında gerçekleştiğinden Yunan ordusunun bu olayları neden önleyemediği sorusuna da yer veriliyordu. Reşadiye, Soyulcak, Pazarköy gibi Yunan hareketi içersinde yer alan bölgenin bu mezalime maruz kaldığ da sorgulaniyordu. Gemlik'te Yunan kuvveti bulunduğu halde, bölgede 15 Mayıs'ta katliamın yaşanması ayrı bir soru işareti idi. Hızlı, sistemli ve büyük çapta bir yıkım hareketinin yerel çetelerle açıklanması da komisyonun anlamakta zorlandığı konular arasında yer alıyordu. Yunan işgal sınırında sistemli bir imha planının uygulanması açıklanmaya muhtaç noktalardandı.

${ }^{21}$ House of Common Parliamentary Papers, s.4. 
Komisyon üyeleri işgal edilen Yalova ve Gemlik kazalarının sistematik bir yıkıma sahne olduğunu gözlemlemişlerdi. Bu yıkımın da Rum ve Ermeni çetelerince gerçekleştirildiği, Yunan müfrezelerinin de bu katliama yardımcı olduğu elde edilen bulgular olarak rapora yazılmıştı. Raporda Türk nüfusun imhasının kendi işgal alanlarında herhangi bir tehdidin ortadan kaldırılması yanında, ileride bir Yunan Hükümetinin bu topraklarda Rum nüfusun çoğunluğun oluşturmak için uygulanan bir yöntem olarak gösterilmesi kayda değer bir bilgidir. Yunan Hükümetinin Hıristiyanlara ve Türklere karşı yürütülen bu zulmü önemsiz gördüğü, işgal alanlarındaki Yunan makamlarının ve henüz işgal edilmemiş bölgelerden de Ankara Hükümetinin (Kemalistlerin) yağma ve mezalimden sorumlu olduğu vurgulanıyordu. ${ }^{22}$

$\mathrm{Bu}$ bilgiler 1şı̆̆ğnda bölgede ortak bir İtilaf Devletleri jandarmasının kurulması, bu kuvvetin bölgede konuşlandırılıp Yunan komutanların gözetimine verilmesi öneriliyordu. Sekiz yüz Türk göçmenin Yalova, Akköy ve Samanlı'da zor şartlarda bulunduğu, bunların en kısa zamanda İstanbul'a ulaştırılması komisyon üyelerinin isteği olarak 23 Mayıs 1921 tarihli raporun sonuç kısmında yer alıyordu.

\section{2-İnceleme Heyetinin Günlüğü}

Raporun bundan sonraki kısmında inceleme heyetinin günlüğü yer almaktadır. İnceleme heyeti 12 Mayıs günü öğle üzeri İstanbul'dan yola çıktı. Öğleden sonra dört buçukta Gemlik'e ulaştı. 10. Yunan Tümeni Kumandanı Leonardopulos heyeti karşıladı. Heyetin incelemelerin yapabilmesi için iki araba tahsis etti. Kız Derbendi, Vezir Han, Elmalık, Fulacık, Lefke ve Küplü'den gelen yüzlerce göçmen Gemlik'e sığınmıştı.

13 Mayıs sabahı inceleme heyeti Yunan hatları içerisindeki Türk köylerini ziyaret etmek için Gemlik'ten ayrıldı. Bir sorunla karşılaşmadan Pazarköy'e (Orhangazi) ulaştı. Yunan ordusu tarafından işgal edilen kasaba birkaç ev dışında tamamen yıkılmıştı. Pazarköy'deki Yunan müfrezesinin kumandanı kendisinin bu zulümlerin yapıldığı sırada, Nisan ayı başında, görevde bulunmayıp, 15 Nisan'da göreve başladığını, kasabanın beşinci piyade alayı tarafından işgal edildiğini ifade etmişti. Kumandanın bu konuşması kasabada Yunan mezaliminin açıkça yapıldığının bir işaretidir. Bursa ve çevresinin işgal edildiği 1920 yılı Ağustos'undan 1921 yılının Mayıs ayı ortalarına kadar Yunan işgali altında kalan bölgenin durumunu açıkça göstermektedir. Kumandan ayrıca kendisinden önceki bir Yunan piyade birliğinin bölgedeki diğer Yunan birlikleri ile temas sağlamak için Bilecik'e gittiğini, yol üzerindeki Rum ve Ermeni köylerinde (Kız Derbendi

${ }^{22}$ House of Common Parliamentary Papers, s.5. 
ve Çengeller) mezalimin gerçekleştiğini ifade etti. Bu iki köydeki halkın yağma hareketine maruz kalmamak için evlerini y1karak Pazarköy'e geldiğini, Türk saldırılarından korunmak amacıyla köyleri kendisinin boşalttırdığını, Rum ve Ermeni göçmenlerin intikam almak için Türklerin evlerini yaktığını belirtti.

Görüşmeden sonra heyet olayları yakından incelemek için Çengeller köyüne gitti. Köy halkı yıkıntılar arasında hayatını sürdürmeye çalışıyordu. Yangından kurtulanlar Türk çetelerin köyü tahrip ettiğini söylediler. Komisyon Pazarköy'e geri döndü. Burada sistematik bir yıkımın gerçekleştirildiği anlaş1lıyordu. Kasaba yıkılmış olsa da, hiçbir kanıta rastlanılamamıştı.

İnceleme heyeti Çeltikçi’ye ulaştığında köy hala yanıyordu. Heyet burada dört Yunan askeriyle karşılaştı. Heyeti görünce şaşıran askerlerin tavrı köyü yakan kişilerin bunlar olduğu düşüncesini uyandırıyordu. Heyet Pazarköy'ün yıkımına ve öldürülen insanlara ait bir iz bulamadı. Dört Yunan askerinin varlığı köyde gerçekleştirdikleri katliamın somut bir göstergesidir. Öldürülen insanlara ait bir iz bulunamaması bu mezalimin sistemli bir şekilde işlendiğine işarettir.

Heyetin diğer inceleme noktası tamamen yakılan Gedelek idi. Yirmi yedi kişinin katledildiğini ileri süren bazı göçmenlerin bu düşüncesini doğrulayacak bir ize ulaşılamadı. Göçmenler heyete yardım eden Süreyya Beye yıkımda etkisi olduğu gerekçesiyle saldırdılar. Süreyya Beyin kim olduğunu dair bir bilgi yoktur. Ancak, bu kişinin Yunan kuvvetlerine yardımc1 olduğu düşünülebilir. İncelemeyi tamamladıktan sonra heyet merkeze geri döndü. Yunanlı bir yetkili merkeze gelerek yaşanan olay hakkında özür diledi.

14 Mayıs günü Gemlik belediye reisinin evinde şikâyetlerin dinlenilmesi için toplanıldı. Belediye reisi heyete öğle yemeği verdi. Heyete şikâyet için gelen ilk kişi (günlükte belirtilmese de muhtemelen Ermeni) Birinci Dünya Savaşı'ndan sonra Ermenilere yapılan zulüm hakkında genel bir özet sundu. Bölgedeki on sekiz köyde nüfusun yetmiş binden iki bin beş yüze indiğini, son Ermeni katliamının bir sene önce (1920) Anadolu'nun İtilaf Devletleri tarafindan işgal edildiğinde yapıldığını abartılı bir şekilde ifade etti. Çengeller, Yeniköy, Keramet ve Mürdegöz'den gelen kişiler 1915 ve 1920 olaylarına işaret ettiler. Zulümler hakkında korkunç hikâyeler anlattılar. Öğleden sonra da heyet şikâyetleri dinlemeye devam etti. Vezirhan, Kız Derbendi, Elmalık, Soyulcak, Çerkesköy, Deli Pazar ve Ortaköy'den gelenler Türk çetelerinin köylerine gelip önce yiyecek, daha sonra at ve diğer hayvanlarını aldıklarını, sonunda bir şey bulamayıp 
yaktıklarını benzer şekilde anlattılar. Şikâyetlerden sonra heyet belediye reisinin evinden ayrıldı.

Ertesi gün heyet yaşananları yerinde görmek için Kumla'ya gitmeye karar verdi. Narlı ve Karaca Ali üzerinde yoğun bir duman görüldüğünden öncelikle bu bölgeye hareket edildi. Öğleden sonra saat iki de Narlı'ya ulaşıldı. Heyet buraya geldiğinde yangın hala devam ediyordu. On yaşlı erkek ile ve genç bir kadın cesedi bulundu. Yaşayan iki erkek de heyete tahsis edilen sağlık merkezinde tedavi altına alındı. Heyet iki buçukta Küçük Kumla'ya ulaştı. Köy tamamen tahrip edilmişti. Köyde zulme maruz kalan birkaç yüz kadın ve erkek heyeti bekliyordu. ${ }^{23}$

Kesin bilgiler elde etmenin zorluğu heyet günlüğünde birçok kez vurgulanmıştı. Günlükte halktan alınan bilgilerle bir Yunan müfrezesi ve Rum çetelerinin birkaç gün önce Küçük Kumla'dan geçtiğine işaret ediliyor, yangın ve mezalimden açıkça belirtilmese de müfreze ve çeteler sorumlu tutuluyordu. Heyet Kumla'nın korunması için acil adımlar atılmasına dair 10. Tümen Kumandanı General Leonardopulos'a mektup gönderdi. Bryony gemisi sahilde bütün gece dolaşarak göçmenlerin güvenliğini sağlamaya çalışt1.

16 Mayıs sabahı heyet halktan bilgi toplamaya devam etti. Bazı göçmenler önceki gün yirmi kişinin ekmek alabilmek için Gemlik'e gitmeye çalıştığını, bunların yolda Yunan müfrezesi ve bir çeteyle karşılaştığını, kadınların geri döndürülüp muhtar da dâhil olmak üzere, erkeklerin bir kısmının öldürüldüğünü söylediler. Sabah saat on da heyet köye ulaştı. General tarafindan gönderilen bir onbaşı ve on muhafiz heyeti korumakla görevlendirilmişlerdi. Heyet bu kişilere de yaşanan olaylarla ilgili sorular sordu. Dönüşte bir Yunan yetkili göçmenlerin korunması için önlem alınacağını ifade etti.

İnceleme heyeti Kapaklıya ulaştığında köyü tamamen yıkılmış buldu. Yıkıntılar içinde korkmuş halde bulunan üç kişi halkın zulümden kurtulmak için dağlara gittiğini söyledi. Köyü gezen heyet dördü kadın olan sekiz ceset ve bir de yaralı buldu. Yaralı merkezde tedavi edilmek üzere gönderildi. Üç kişi kendilerinin daha güvenli yere alınması hakkında yardım istediler. Halkın dağlara çekildiğini, eğer güvenlik sağlanırsa ertesi gün sahilde toplanabileceğini belirttiler. Heyet akşam tekrar Küçük Kumla'ya geri döndü.

17 Mayıs günü iki Yunan yetkili ve Gemlik-Armutlu arasındaki güvenliği sağlamakla görevli müfreze ile birlikte heyet merkezine geldi.

\footnotetext{
${ }^{23}$ House of Common Parliamentary Papers, s.5-7.
} 
Heyet bunları sorguladı. Yunan müfrezesinin Gemlik-Armutlu arasında geçtiğini bildiğinden olaylan bu birliğin işlediğini düşünüyordu. Yunan askerleri sadece bir Türk'ü dövdüklerini, fakat başka bir suça karışmadıklarını ileri sürdüler. Dağlara çekilen iki yüz göçmeni taşımak için iki motor gönderildi. Sabah saat on da Küçük Kumla'dan Fıstıklı'ya gitmek için heyet ayrıldı. Fıstıklı'ya gelen heyet köyü sağlam buldu. Köyde tacirler zeytin alımıyla uğraşıyorlardı.

Fistıkl1'daki incelemelerini tamamlayan heyet gece yarıs1 Armutluya ulaştı. Kasaba gayet güzel ve bakımlı idi. Müfreze komutanı kasabayı korumakla görevli olduğunu, halk arasında bir sorun yaşanmadığını belirtti. Komisyonun çağırdığı Türk ve Rum temsilciler toplu haldeki görüşmelerde birbirlerinden şikâyetçi olmadılar. Ayrı sorgulandıklarında aralarındaki geçimsizlikleri anlattılar. Heyet Küçük Kumla'dan gelen iki motor dolusu göçmeni karş1lamaya gitti. Bir Kızılhaç yetkilisi Rum çete reisi ile görüştüğünü, reisin gözetleme gemisi Bryony'in ayrılmasından sonra Kumla'ya gelip yağmalayacağını iletti. Geminin gece boyunca sahilde gözetleme yapması kararlaştıııldı. ${ }^{24}$

18 Mayıs sabahı gözetleme gemisi Bryony Gemlik'e geri döndü. Komisyon Müslümanlarla dolu camiyi ve bir mahalleyi ziyaret etti. Halkın durumu çok kötü olup yiyecekleri yoktu. Göçmenlerin daha güvenli bölgelere gönderilmeleri gerekiyordu. Merkeze dönen heyete ulaşan telgrafta İnebolu gemisinin göçmenleri almak için İstanbul'dan ayrıldığ bildiriliyordu. Gemlik'e dönen heyet belediye reisini ziyaret ederek göçmenlerin gönderileceğini bildirdi. Komisyon altı buçukta Küçük Kumla'ya gitti. Saat dokuzda göçmenlerle birlikte merkeze geri döndü. Öğleden sonra saat iki de göçmenlerin gemiye bindirilmesi tamamlandı. İnebolu gemisi İstanbul'a gitmek için Gemlik'ten ayrıldı.

19 Mayıs sabahı gözetleme gemisi Küçük Kumla sahili boyunca denetimini sürdürdü. Öğleden sonra saat bir de eşkıya reisi Hacı Yorgi merkeze getirildi. Sorgusunda sarhoş olduğunu, sadece Yunan müfrezesine yardım ettiğini söyledi. Akşama doğru İnebolu gemisi ve diğer üç motor kalan göçmenleri almak için geri döndü.

20 Mayıs sabahı gözetleme gemisi ve Kızıl Haçın beraberinde götürdüğü motorlar Gemlik'e gitmek üzere Kumladan ayrıldı. Komisyon göçmenlerin gönderilme çalışmalarını kontrol etmek için sahile gitti. Öğleden sonra üç buçukta göçmenlerin gemiye sevki tamamlandı. 21 Mayıs sabahı gözetleme gemisi Bryony Yalova'ya ulaştı. Bölgedeki Yunan

\footnotetext{
${ }^{24}$ House of Common Parliamentary Papers, s.7-8.
} 
Müfreze Kumandanlığına heyetin geldiğine dair temsilci gönderildi. Saat dokuzda merkeze gelen Yunan Kumandanı sorguland1. Sorguda kendisinin bir ay önce Yalova'ya geldiğini, burada köyleri yanmış halde gördüğünü, çevrede çetelerin bulunduğunu, kendi güçlerinin ancak kasabayla sinırlı olduğunu ifade etti. Kumandanın bu kayıtsızlığı olayları yakından takip etmekle birlikte, önlenmesi adına bir çaba göstermediği, muhtemelen çetelere lojistik destek sağladığı düşünülebilir.

Kıyıya çıkan komisyon bir grup Rum göçmenle karşılaştı. Çoğunluğu Fulacık'tan olan göçmenlerin şikâyetleri dinlendi. Komisyona çağrılan kaymakam da Yalova hakkında bilgi verdi. Savaştan önce Yalova bölgesinin yarı yarıya Türk ve Rum olduğunu, kasabanın ise sadece Türklerle meskûn olduğunu; şimdi kasabada üç yüz, Samanlı ve Akköy'de birkaç yüz Türk kaldığını söyledi. Heyet Rum mahallelerini ziyaretinde öfkeli bir grupla karşılaştı. Komisyona yardım eden Hafız Ahmet ve diğer bir Türk'ün bölgedeki katliamlara karıştıklarını iddia ederek tepki gösterdiler. Hafız Ahmet öfkeli kalabalığın elinden motorun arkasından suya girerek kurtulabildi. Aynı gün öğleden sonra iki buçukta komisyon Çınarcık'a ulaştı. Kasaba camii dışında yıkıma uğramamıştı. Mezalime dair bir iz bulunamadı. Heyet Kocadere'yi ziyarette köy tamamıla yıkılmış buldu. Ölenlere dair bir bilgiye ulaşılamadı. Komisyon gözetleme gemisine geri döndü. İstanbul'a doğru hareket eden gemi 22 Mayıs sabahı İstanbul'a vard1. ${ }^{25}$

Bu günlüğün ardından inceleme heyeti Yüksek Komiserliğe sunulan bir rapor hazırladı. Dört maddede hazırlanan bu raporda geçen on iki ayda Türkler ve Rumlar tarafından gerçekleştirilen zulüm ve yağmaya dair çeşitli kanıtların bulunduğu belirtiliyordu. Türk bölgelerindeki mezalimin Rum köylerine göre daha şiddetli ve dikkate değer olduğu ifade ediliyordu (madde 1). Heyetin dinlediği kişilerin yaptıkları açıklamaların korkutucu, heyecan verici olduğu(madde 2),Yunan ordusunun işgal alanında özellikle ilerleme aşamalarında bu olayların daha da arttığı vurgulanıyordu. ${ }^{26}$ Türk nüfusun bulunduğu kıyı kesimlerde yıkımların artış gösterdiğine, Yunanlıların kendi politikalarını gerçekleştirmek adına bir çözülmeye yol açması için mezalimi desteklediklerine dikkat çekiliyordu. Türklere ait teşkilatlardan yardım alınması savunuluyor, bu yardımın yaygınlaştırılması için İstanbul Hükümetine destek verilmesi gerektiği, sık düzenlenecek raporların önlem alınmasında katkısı olacağı belirtiliyordu (madde 4). Bu maddenin eklerinde

\footnotetext{
${ }^{25}$ House of Common Parliamentary Papers, s.9.

${ }^{26}$ Heyetin çalışmalarını sürdürdüğü sırada Yunan ordusunun da Trakya'dan getireceği 12. Tümenle birlikte 175.000 kişiye ulaşacağını, muhtemelen üç hafta içinde etkili bir saldırıda bulunacaklarına dair İzmir'deki İngiliz temsilci H. Lamb Lord Curzon'u bilgilendirdi. Foreign Office E 6569/143/44, Sir H.Lamb’tan Earl Curzon'a, İzmir, 7 Haziran 1921.
} 
zor duruma düşen insanların kendilerini korumak için bazen çete faaliyetlerine giriştikleri, 11. Yunan Tümeni bölgesi olan İzmit yarımadasında göçmen sayısının on beş bine çıtığı, Türklerin Rum çete ve Yunan askerlerinden, Rumların da Türk çetelerinden korkarak yaşadıkları ifade ediliyordu. Rum göçmenlerin Yunan Hükümetinin ya da İtilaf Devletlerinin gözetiminde bir bölgede bulundurulması, Ermeniler için de güvenli bir bölge oluşturulması öneriliyordu. Türk ve Rum çetelerin denetime alınabilmesi için de her iki yönetimin etkinleştirilmesinin yararlı bir girişim olacağ ileri sürülüyordu.

$\mathrm{Bu}$ rapordan sonra Yunan ordusunun aşırılıkları üzerinde duruluyordu. Yunan ordusu Temmuz ve Ağustos'ta (1920) bölgeyi işgal ettiğinde halkın öldürüldüğü, hayvanların gasp edildiği, köylerin yakıldığı dile getiriliyordu. Bireysel hareketlerin disiplinsizliğe yol açtığ 1 , bir süre sonra da bunun önünün alınamadığı vurgulanıyordu. Mart ve Nisan aylarında köylere yönelik saldırıların artış gösterdiği, saldırıların İzmit yarımadasından Adapazarı'na yayıldığı, insanların katledildiği, kadınlara tecavüz edildiği ifade ediliyordu. İşgal sırasında gerekli önlemleri almayıp bu olayların meydana gelmesine neden olan Yunan makamlarının, Türk ve Rum çetelerin zulmünün artmasında etkili olduğuna dikkat çekiliyordu. Gerekli tedbirlerin kolaylıkla alınabileceği, Yunan askeri görevlilerinin ordunun düzeni ve diğer işlerle ilgilendiklerinden bunu yerine getirmekte ya yetersiz kaldıkları, ya da işi savsakladıkları belirtiliyordu. Yunan işgal bölgelerinde Rum köylerinin Türkler tarafindan yakıldığına, buna misillime olarak Yunan işgal sınırı içinde kalan Türk köylerinin de aynı akıbete uğradığına, misillemelerin de Türk ve Rum köylerinin yakılıp yıkılmasına, halkın katledilmesine sebep olduğuna yer veriliyordu. İzmit'in doğu kesiminde Yunanlıların otuz binden fazla Çerkesi kendilerine yardım ermek üzere göçmen olarak bölgeye getirdikleri, bunların Ankara Hükümetinin düşmanı olarak yer aldıkları belirtilen konular arasındaydı. Çerkeslerin bu yönetim boşluğu içerisinde çeteler kurması, Yunanlıların bölgedeki otoritelerini güçlendirmek adına attıkları adımlar arasında gösteriliyordu. Bölgede etkin önlemler alamayan Yunan ordusu zulüm ve mezalimden sorumluydu.

Türklere ait aşırılıklar kısmında Rumlara karşı yapılan saldırılara değiniliyordu. Saldırılar 1920 Mart ayından itibaren ve özellikle Yunan taarruzunun arttığı Haziran ve Temmuz aylarında yoğunlaşmıştı. Kuva-yı Milliye ve batı cephesinin kurulmasıyla İzmit sancağında Türk çeteleri etkili olmaya başladılar. Bu çeteler diğer Türk köylerinden lojistik destek alıyordu. Adapazarı'nın kuzey ve kuzey-doğusu, İzmit'in güney ve güney doğusu bu yıkımdan fazlasıyla etkilenmişti. Temmuz 1920'den itibaren Yunan 
taarruzunun yarımadanın güney doğu kesiminde, özellikle de Karamürsel civarında, Kuva-yı Milliyenin aşılamadığı ifade ediliyordu.

Çete faaliyetlerinin 1921 ilkbaharından itibaren İzmit'in güney kesimine yayıldı, Bahçecik hariç bütün Rum ve Ermeni köyleri yıkıldı. Yunan makamlarının otuz iki köyün yıkılıp yakıldığı, on iki binden fazla insanın katledildiği, iki bin beş yüz kişinin kaybolduğu, on beş bin kişinin de İzmit'te göçmen olarak bulunduğu bilgisine yer veriliyordu. Bu bilgilerin dönemin nüfus yapısıyla uyuşmayıp abartılı olduğu anlaşılmaktadır. ${ }^{27}$

\section{Sonuç}

İtilaf Devletlerine yansıyan çeşitli şikâyetler neticesinde Yalova ve İzmit çevresine bir araştırma komisyonunun gönderilmesi kararlaştırıldı. ${ }^{28}$ Komisyonun yerinde inceleme yaparak hazırladığ1 rapor Sakarya Savaşı öncesinde bölgenin durumunu göstermesi bakımından önem taşımaktadır. 12 Mayıs'ta Gemlik'e gelen komisyon 21 Mayıs'a kadar bölgedeki incelemelerini sürdürdü. Komisyon raporu yanında, izlenimlerin belirtildiği günlüğün de bulunması belgenin önemi arttırmaktadır.

Komisyonun incelemelerini Hıristiyan köyleri üzerinde yoğunlaştırdığı görülmektedir. Halkın Türk çetelerinden şikâyetlerine raporun birçok yerinde yer verilmiştir. Türk köylerine yapılan mezalim belirtilmekle birlikte, bunu muhtemel sebepleri üzerinde durulmamaktadır. Yunan ordusu ve Rum çetelerin yıkım ve zulümlerine daha az yer verilmiștir. Türk köylerine yapılan zulümlerde Yunan askerlerinin planlı yıkım ve tahribatı belirtilmişse de, bu zulümlerin durdurulması konusunda sunulan önerilerin etkili tedbirler olduğunu söylemek mümkün değildir.

Komisyonun Küçük Kumla'daki göçmenlerin daha güvenli bölgelere gönderilmesi konusundaki gayreti sonuç verdi, göçmenler İnebolu vapuru ve diğer üç tekne ile İstanbul'a gönderildiler. Dağlara sığınan göçmenler bir mezalimden kurtulabildiler. Diğer köylerde (Karaca Ali, Narlı, Çengeller, Çeltikçi, Gedelek, Kız Derbendi, Kocadere, Fulacık, Soyulcak) büyük bir tahribat yaşanmış, halkın büyük bir kısmı öldürülmüş, çok az kişi sağ kalabilmişti.

Türk ve Yunan ordusunun bölgedeki konuşlanışı üzerine yeterli bir bilgi olmayıp, sadece Gemlik’te 10. Yunan Tümeninin varlığından söz ediliyor,

\footnotetext{
${ }^{27}$ House of Common Parliamentary Papers, s.10-11.

28 İtilaf Devletleri temsilcilerinin 21 Şubat 1921 tarihli görüşmede İzmit bölgesi gündeme geldi. Yunan temsilcisi M. Kalogeorupoulos yakında İzmit bölgesine yeni kuvvetlerin gönderileceğini söyledi. Foreign Office E 1266/1/44.
} 
araştırma alanı içerisindeki bazı birliklerin sadece yerleri belirtiliyor, lojistik durumları hakkında herhangi bir somut bilgiye yer verilmiyordu.

10.Yunan Tümeni Kumandanı Leonardopulos tarafindan komisyonun kabul edilmesine rağmen, bölgedeki gelişmeler konusunda tatmin edici bilgi verilmediği rapora yansıyan ifadelerden anlaşılmaktadır.

Kuva-yı Milliyeden orduya geçiş aşamasıyla birlikte batı cephesinde önemli bir döneme girildi. 1921 yılı ortaları itibariyle Yalova ve İzmit bölgelerinde yaşanan çeşitli zulümler neticesinde yapılan şikâyetlerle İtilaf Devletleri bir komisyon teşkil ettiler ${ }^{29}$ İngiliz, İtalyan ve Fransız temsilcilerinden oluşan inceleme heyeti de bu zulümleri yerinde araştırmak için 12 Mayıs'ta bölgeye geldi, on günlük bir sürede gözlemlerini rapor haline getiren heyet temsilcileri birer kopyasını kendi devletlerine gönderdiler. ${ }^{30}$

İstanbul'daki İngiltere temsilcisi Mr. Rattigan heyet çalışmalarına Lord Curzon'a gönderdiği yazıda değiniyordu. Rattigan, İtilaf Devletlerinin İzmit ve çevresindeki katliamları araştırmak için bir heyet gönderildiğini, Rum ve Ermeni çeteleri ve Yunan kuvvetlerinin İzmit çevresinde katliam ve zulüm yaptığını belirtiyordu. Yunan otoritelerinin de katliamların durdurulması adına hiçbir adım atmadıkların ifade ediyor, İtilaf Devletleri Yüksek Komiserliğinin Yunan Yüksek Komiserliğine mezalimin önlenmesi konusunda bu rapora dayanarak bir nota verdiğine yer veriyordu. ${ }^{31}$

Rapor göçmenlerin daha güvenli bölgelere yerleştirilmesinden başka bölgede asayişin sağlanmasına katkıda bulunacak somut öneriler içermiyordu. Türk ordusunun batı cephesinde kazandığı iki savaştan sonra, daha büyük bir zaferin öncesinde bir rapor hazırlanması İtilaf Devletlerinin bölge halkı üzerinde olumlu izlenim bırakma düşüncesinin sonucu olarak görülebilir.

Kaynakça

a- Arşiv Belgeleri

Başbakanlık Osmanlı Arşivi, Bab-1 Ali Evrak Odası, Dâhiliye Gelen-Giden Defterler.

Dâhiliye Nezareti Kalem-i Mahsus Müdüriyeti.

\footnotetext{
${ }^{29}$ İtilaf Devletleri’nden Fransa ve İngiltere'nin Milli Mücadele hareketi ile Londra'da 11 Mart 1921'de imzaladıkları anlaşmalar vardır. The Manchester Guardian, "Franco-Italian Agrements with the Kemalists", 11 Nisan 1921.

30 Milli Mücadelenin İngiliz kamuoyundaki yansımaları da göz ardı edilemez. The Manchester Guardian (1901-1959), "Kemalists Evacuating Angora",27 Jul.1921.

${ }^{31}$ Foreign Office, E 7643/143/44, Mr Rattigan'dan Curzon'a, İstanbul, 5 Temmuz 1921.
} 
Başbakanlık Cumhuriyet Arşivi, Bakanlar Kurulu Ortak Kararları.

Genelkurmay Başkanlığı ATASE Arşivi, Türk İstiklal Harbi Katalogu.

Türk Tarih Kurumu Arşivi, Bekir Sami Bey Dosyası.

Foreign Office

House of Common Parliamentary Papers, 1921, [Cmd 1478], Turkey, No.1, (1921).

\section{b- Gazeteler}

Manchester Guardian (1921)

New York Times (1921)

\section{c-Makale ve Kitaplar}

Atatürk, Mustafa Kemal, Nutuk, C.I, İstanbul, 1984.

B.M.M Zabut Ceridesi, Devre 1, C. 3, Ankara, 1959.

Birinci, İhsan, "Milli Mücadele için Kurulan Önemli Cemiyet ve Çeteler", Hayat Tarih Mecmuasl, Sayı 10-11 (Eylül 1971), İstanbul, 1971.

Cebesoy, Ali Fuat, Milli Mücadele Hatıralarl, İstanbul, 1953.

Eğilmez, Mümtaz Şükrü, Milli Mücadelede Bursa, İstanbul, 1984.

Erdeha, Kamil, Milli Mücadele Vilayetler ve Valiler, İstanbul, 1975.

Gizli Oturumlarda Atatürk'ün Konuşmalarl, (hazırlayan Sadi Borak), İstanbul, 1977.

Gürler, Hamdi, Kurtuluş Savaşı’nda Albay Bekir Sami-Günsav- (Mayıs-Haziran 1919), Genelkurmay Başkanlığı Yayınları, Ankara, 1994.

Meral, İbrahim, Mütarekeden Cumhuriyet'e (30 Ekim 1918-29 Ekim 1923) Azınlıkların Sosyal, Ekonomik ve Demografik Yapısı ve Dış Ülkelerle Olan ilişkileri, Hacettepe Üniversitesi Atatürk İlkeleri ve İnkılap Tarihi Enstitüsü Yayınlanmamış Doktora Tezi, Ankara, 1997.

Özalp, Kazım, Milli Mücadele, C.I, Ankara, 1985.

Özel, Sabahattin, Kocaeli ve Sakarya İlerinde Milli Mücadele, İstanbul, 1987.

Sarıhan, Zeki, Kurtuluş Savaşı Günlüğü, C. III, Ankara, 1986.

Selçuk, İlhan, Yüzbaşı Selahattin 'in Romanı, C.II, İstanbul, 1987.

Sofuoğlu, Adnan, Milli Mücadele Döneminde Kocaeli, Ankara, 2006.

Şehir ve Kasabaların Harp Bölgeleri Bombardıman, İsgal ve Kurtuluş Tarihleri 1911-1922, Genelkurmay Harp Dairesi Başkanlığ 1, Ankara, 1977.

Turan, Şerafettin, Balıkesir ve Alaşehir Kongreleri ve Hacim Muhittin Çarıklı'nın Kuva-yı Milliye Hatıraları, Ankara, 1967.

Türk Ístiklal Harbi, C.2, T Kısım 4, Ankara, 1974.

Yüceer, Saime, Bursa'nın İşgali ve Kurtuluş Süreci, Bursa, 2001. 